Review

\title{
REHABILITATION TREATMENT IN PATIENTS WITH URINARY INCONTINENCE
}

Cvetanka Gjerakaroska-Savevska ${ }^{1}$, Erieta Nikolikj- Dimitrova ${ }^{1}$, Valentina Koevska ${ }^{1}$, Biljana Mitrevska ${ }^{1}$, Marija Gocevska ${ }^{1}$, Daniela Gecevska ${ }^{1}$

1 Institute of Physical Medicine and Rehabilitation; Faculty of Medicine, Ss Cyril and Methodius University, Skopje, Republic of North Macedonia

Citation: Gjerakaroska-Savevska C, Nikolikj- Dimitrova E Koevska V Mitrevska B, Gocevska M, Gecev1kn D. Rehilitation treatment in patients with ska D. Rehabilitation treatment in patients wit urinary incontinence. Arch Pub

Key words: urinary incontinence, exercise, physical therapy, rehabilitation

*Correspondence: Erieta Nikolikj- Dimitrova. Institute of Physical Medicine and Rehabilitation, Skopie, Republic of North Macedonin E-mail: ma Skopje, Republic or Received: 29-Apr-2020; Revised: 3-Jul-2020 Accepted: 15-Jul-2020; Published: 15-Dec-2020

Copvright: ${ }^{\circ}$ 2020. Erieta Nikolikj- Dimitrova. This is an open-access article distributed under The is an open-access article distributed under the terns of the Creative Commons Attribution License, which permits unrestricted use, distribution, and reproduction in any medium, provide the original author(s) and source are credited.

Competing Interests: The author have declared that no competing interests

Преглед на литература

\section{Abstract}

Urinary incontinence is the inability to control urination with spectrum of disturbances from periodical urinary leaks to complete inability to retain urine. It occurs more often in elderly and in women. Urinary incontinence has a great impact on general health and may reduce the quality of life. There are several types: stress urinary incontinence, urgent urinary incontinence, neurogenic urinary incontinence, overflow urinary incontinence. Stress urinary incontinence is the most frequent one and is due to pelvic floor muscle weakness. For assessment and treatment of these patients the individual approach is warranted. The treatment of these patients includes medications, behavioral therapy, biofeedback, pelvic floor muscle training, electrical stimulation, magnetic stimulation and surgery. Non-surgical treatment might be effective to prevent surgery. Rehabilitation treatment with pelvic floor exercises and physical modalities for patients with urinary incontinence is important for recovery of the urinary continence and improvement of quality of life in these patients.

\section{РЕХАБИЛИТАЦИСКИ ТРЕТМАН НА ПАЦИЕНТИ СО УРИНАРНА ИНКОНТИНЕНЦИЈА}

Цветанка Геракароска-Савевска ${ }^{1}$, Ериета Николиќ-Димитрова ${ }^{1}$, Валентина Коевска ${ }^{1}$, Билјана Митревска ${ }^{1}$, Марија Гоцевска ${ }^{1}$, Даниела Гечевска ${ }^{1}$

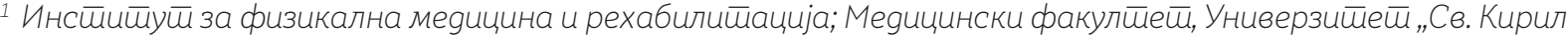
меш̄оguj" во Скойје, Рейублика Северна Макеgонија

Цитирање: Геракароска-Савевска Ц, Николиќ-Димитрова Е, Коевска В, Митревска Б, Гоцевска М, Гечевска Д. Рехабилитациски трет ман на пациенти со уринарна инконтиненција. ман на пациенти со ури Apx Здравје 2020;12(3)

Клучни зборови: уринарна инконтиненција, вежби, физикална терапија, рехабилитација.

*Кореспонденција: Ериета Николиќ-Димитрова, Институт за физикална медицина и рехабилитација Скопје, Република Северна Македонија. E-mail: erietand@yahoo.com

Примено: 29-мај-2020; Ревидирано: 3-јул-2020 Прифатено: 15-јул-2020; Објавено: 15-дек-2020

Печатарски права: ${ }^{\circledR 2020}$ Ериета Николиќ-Димитрова. Оваа статија е со отворен пристап дистрибуирана под условите на нелокализирана лиценца, која овозможува неограничена употреба, дистрибуција и репродукција на било кој медиум, доколку се цитираат оригиналниот(ите) автор(и) и изворот.

Конкурентски интереси: Авторот изјавува дека нема конкурентски интереси.

\section{Извадок}

Уринарна инконтиненција, односно неможност за контролирање на мокрењето опфаќа спектар на пречки од повремено истекување на урината до комплетна неможност за задржување на урината. Почеста е кај повозрасната популација и кај жените. Уринарната инконтиненција во голема мерка влијае врз нарушување на општото здравје и го намалува квалитетот на живот. Таа може да се групира во неколку типови: стрес инконтиненција, ургентна инконтиненција, неврогена инконтиненција, преливна "overflow" инконтиннеција. Стрес инконтиненцијата е најчеста од горенаброените, настанува заради слабост на мускулите на карличното дно. Потребен е индивидуален пристап во проценка на состојбата и во изборот на третманот. Можностите за третман вклучуваат медикаментозна терапија, бихејвиорална терапија, биофидбек, вежби за јакнење на карличното дно, електрична стимулација, магнетна стимулација и хируршки третман. Нехируршките третмани можат да бидат успешен терапевтски пристап со цел да се спречи потребата од хируршки третман. Рехабилитационен третман со примена на вежби и физикални агенси кај пациенти со уринарна инконтиненција е значајни во обновување на континенцијата и подобрување на квалитетот на живот кај овие пациенти. 


\section{Вовед}

Според Интернационалното здружение на континенција, уринарната инконтиненција се дефинира како неволен проток на урина во кое било време ${ }^{1}$. Неможноста да се контролира уринирањето опфаќа спектар на пречки од повремено истекување на урината до комплетна неможност за нејзино задржување.

Во светот 200 милиони луѓ (секоја втора жена и секој четврти маж) страдаат од некој степен на уринарна инконтиненција ${ }^{1,2}$. Преваленцијата на уринарна инконтиненција кај жени како почесто афектиран пол варира широко во светски рамки, од 5-70\%, при што повеќето студии известуваат за преваленција од 25-45\%. Притоа треба да се нагласи дека преваленцијата се зголемува со зголемување на возраста, па така повеќе од 40\% од жените над 70 години се афектирани. Пријавената инциденција на уринарна инконтиненција се движи од 1\% до 9\%, додека проценките за ремисија се различни, од $4 \%$ до $30 \%^{3}$. И покрај високата преваленција, уринарната инконтиненција останува да биде потценета состојба на која не и е посветено должното внимание.

Уринарната инконтиненција се групира во неколку типови: стрес инконтиненција, ургентна инконтиненција, преливна (“overflow”) инконтинеција и неврогена уринарна инконтиненција ${ }^{1,2}$.

Стрес инконтиненција подразбира несакана загуба на урина кога се интактни долните уринарни патишта, во услови при најмал напор кои го зголемуваат интраабдоминалниот и интравезикалниот притисок (кашлање, кивање, смеење, спортска активност, подигање на тежок товар).

При овие состојби интравезикалниот притисок го надминува при- тисокот во уретрата во отсуство на контракција на детрузорот што резултира со несакано испуштање на урина. Не постои спонтана потреба за празнење на мочниот меур, а урина се губи и кога содржи многу мали количини. Ова особено се случува во исправена положба; тогаш вратот на мочниот меур е на најниска точка без потпора и се наоѓa во точка на комбиниран интраабдоминален притисок и максимална гравитациона сила при што трпи компресија. Кај стрес инконтиненцијата нема оштетување на сфинктерниот механизам, но пелвичното дно заради хипотонија и намален еластицитет на мускулите и сврзното ткиво престанува да биде потпора на везикоуретралниот сегмент и настанува алтерација на везикоуретралниот агол. Од сите пациенти со уринарна инконтиненција, 88\% имаат стрес инконтиненција, а до $75 \%$ се од женски пол ${ }^{1,2}$.

Како предиспонирачки фактори се наведуваат: пролапс на мочен меур или дебело црево, мултипни породувања и породилните трауми (стаза и исхемија на карличните сврзномускулни ткива, истегнување и руптура на мускулните влакна - доказ за ова е доцнење во нервниот пренос кај напречнопругави мускули на сфинктерот на уретрата и карличното дно), конгенитална или стекната мускулна слабост на карличното дно, седентарен начин на живот, менопауза/хипоестрогенизам, хронична кашлица, зголемена телесна тежина, намалена спортска активност, хистеректомија или хируршка интервенција на карличното дно, цивилизирана потреба од користење на WC школка, примена на диуретици, консумирање големи количини кофеинизирани пијалоци 4 .

Ургентна инконтиненција се јавува поради ненадејни контракции на мочниот меур во фазата на полнење 
што резултира со ненадејна, интензивна и честа потреба за уринирање со несакана загуба на урина. Во овој случај карличното дно дава соодветна поддршка и нема анатомски промени на везикоуретралната анатомска структура, сфинктерниот механизам е компентентен, но постои силна иритабилност на детрузорот. Причината за овие нестабилни контракции кои предизвикуваат брза потреба од микција може да биде хиперсензитивност на детрузорот, негова прекумерна активност, зголемена стимулација или дефицитна инхибиција на функцијата на мочниот меур. Како причина за иритабилноста може да бидат инфламаторни состојби, неоплазма, камен во везиката ${ }^{1,2}$. Овој тип на инконтиненција се јавува кај 7-33\% од вкупната популација (22\% од жените наспроти 2,6\% од мажите) $)^{3}$.

\section{Преливна (“overflow") уринар-} на инконтиненција се јавува како резултат од намалена активност на детрузорот или субвезикална опструкција (зголемена простата, туморозни формации, фиброзно ткиво) при што мочниот меур некомплетно се празни, а пак, тоа доведува до претекување и постојано истекување на урина. Многу пациенти од машки пол страдаат од умерена до тешка преливна уринарна инконтиненција во првите постоперативни недели до неколку месеци па и години по радикална простатектомија при третман на канцер на простата. Причина за инконтиненцијата по простатектомија може да се должи на слабост на внатрешен сфинктер или прекумерна активност на детрузорот. Инциденцијата на инконтиненција по радикална простатектомија се движи од 6\% до $87 \% 1,3$. Најважен пристап во конзервативниот третман кај овие мажи е вежби за тренинг на мускулите на карличното дно. Овие вежби ја ре- дуцираат фреквенцијата на епизодите на инконтиненција од 54-72\%3

Неврогената уринарна инконтиненција е чест симптом при нарушено функционирање на нервниот систем (цереброваскуларен инсулт, Алцхајмерова болест, мултипна склероза, Паркинсонова болест, дископатии, лезии на кауда еквина, трауматски повреди на рбетниот мозок, дијабетична или алкохолна невропатија). Испитувањата докажале дека 40-60\% од пациентите со цереброваскуларен инсулт се соочуваат со инконтинеција една недела по лезијата, до 33\% во првите 3 месеци, а 14-15\% 6 месеци по инсултот. Причина за ова е хиперрефлексија на детрузорот со неинхибирани контракции на мочниот меур поради ослободување на рефлексите за уринирање во медула спиналис од повисоките инхибиторни центри 5 .

\section{Дијагноза на уринарна инконтиненција}

Дијагностиката на уринарна инконтиненција опфаќа детална анамнеза со наведени симптоми и жалби за зачестеност, итност и чувство на намокреност, клинички преглед, уринокултура и биохемиски преглед на урина. Следно е ренален ултразвучен преглед и уродинамски испитувања (цистометрија, сфинктерометрија и урофлоуметрија кои опфаќаат мерење на притисокот и брзината на проток на урина во мочниот меур и уретрата како и мерење на резидуална урина) ${ }^{6}$.

Овие скорови се користат во проценка на пациенти со уринарна инконтиненција :

- The International Consultation on Incontinence QuestionnaireShort Form (ICIQ-SF) score

- Gaudenz Questionnaire 
- Overactive bladder symptom questionnaire (OAB-q)

- Urogenital distress inventory questionnaire short form (UDI-6)

- Incontinence impact questionnaire - short form (IIQ-7)?

Доколку не се лекува уринарната инконтиненција може да предизвика кожни лезии (црвенило, чешање, инфекција, мацерација на кожата и декубитални рани заради константно влажната кожа), зголемен ризик од инфекции на уринарниот тракт, психосоцијални последици (депресија, изолација), причина за чести падови и последователни фрактури ${ }^{3}$.

Уринарната инконтиненција е често мачна и занемарувана состојба, влијае негативно на социјалниот живот, извршување на работните задачи и личните односи што води кон намален квалитет на живот. Индивидуалниот пристап и проценка на состојбата се повеќе од важни за да се одбере иницијалниот третман.

Целта на трудот е да се прикажат најновите сознанија за современите методи на физикална терапија и рехабилитација во третманот на пациенти со уринарна инконтиненција.

\section{Материјал и методи}

За овој ревијален труд беа истражувани најнови објавени трудови од областа на конзервативниот третман со примена на физикални агенси и рехабилитациски постапки во современ третман на пациенти со уринарна инконтиненција. Пребарувањето беше извршено во следните електронски бази на податоци: PubMed, Cochrane Library, Hinari за период од 2006 до 2019 година. Како клучни зборови се користеа: urinary incontinence, rehabilitation, exercises, physical therapy, magnetic stimulation.

\section{Резултати}

Широк е дијапазонот на тераписките можности, почнувајќи од промени во животниот стил па сѐ до инвазивни хируршки интервенции. Методите вклучуваат промени во животниот стил, бихејвиорална терапија, вежби за јакнење на мүскулите на карличното дно, физикални агенси, медикаментозна терапија и хируршки третман.

Очекуваните резултати кај лицата со лесна до умерена уринарна инконтиненција кои учествуваат во индивидуализирани програми за конзервативен третман се генерално добри, со голема веројатност за значително подобрување на симптомите и подбрување на квалитетот на живот. Бројните нехируршки третмани се лесно достапни, економични и доколку се применуваат редовно може да бидат успешен терапевтски пристап со цел да се спречи потребата од хируршка интервенција. Прв избор на третман се најмалку инвазивните техники ${ }^{4,8}$.

Промените во животниот стил опфаќаат намален внес на алкохол, цигари и кофеин особено пред спиење, контрола на внес на течности, намалување на зголемената телесна тежина. Во студија на пациенти со стрес уринарна инконтиненција кои изгубиле најмалку 3-5\% од нивната базична тежина постигнале $47 \%$ редукција во епизодите на инконтиненција 9

\section{Бихејвиорален третман}

Бихејвиоралниот третман опфаќа тренинг на мочниот меур, односно едукација за негово празнење, седнување на тоалетна школка во одредени временски интервали и празнење на мочниот меур. Пациентите се учат да се празнат пред да 
добијат нагон и чувство на исполнетост, односно пред да го достигнат полниот капацитет на мочниот меур. Помеѓу секое уринирање пациентите се поттикнуваат да земат течности при што капацитетот на мочниот меур се зголемува, а честотата на уринирање се намалува. Постепено се зголемува временскиот интервал помеѓу празнењата за 10-15 минути на секои 2 до 5 дена. На овој начин се зголемува капацитетот на мочниот меур, а честотата на мокрење се намалува. Третманот вклучува и барање од пациентот да уринира во сад со тесно грло со обиди да не го промаши садот, да го стопира уринирањето и повторно да го отпочне, што е одлична вежба за надворешниот сфинктер. Тренингот на мочниот меур е особено важен кај оние кои имаат стрес или ургентна инконтиненција. Овој пристап е важен и за пациенти со сочувана, но и со нарушена когнитивна функција. Пациентите со нарушена когнитивна функција треба редовно да се контролираат колку течности внесуваат и редовно да се поставуваат да уринираат според однапред одреден распоред ${ }^{10}$. Бихејвиоралниот третман кај 57-86\% од случаите има ефикасност во намалување на фреквенцијата на уринирање ${ }^{8}$.

\section{Кинезитерапија}

Кинезитерапијата е база на рехабилитациониот третман. Јакнење на периуретралните мускули, особено на пубококцигеалниот мускул, е од исклучително значење. Овој мускул се состои од брзи и бавни мускулни влакна инервирани од пуденталниот нерв. Повторувани контракции на мускулите на карличното дно ги стимулира бавните влакна, додека вежби со отпор и вежби со голема брзина имаат влијание на брзите влакна. Кегеловите вежби се дел од кинезитерапијата и опфаќаат сакани контракции на периуретралните мускули во различни позиции, вежби за спиналните екстензори, вежби за стабилизација на трупот, вежби за инклинација на карлицата, вежби за релаксација, вежби за дишење со вклучување на дијафрагмата. При изведување на вежбите многу е важно на пациентот да му се нагласува да биде постојано свесен за секоја контракција и релаксација затоа што само на тој начин ќе се здобие со сакана контрола на мускулите на карличното дно ${ }^{4,11}$.

Систематски преглед на клинички студии кои го испитувале ефектот на вежбите за карличното дно кај стрес инконтиненција укажува на стапка на излекуваност од 58,8\% 12 месеци по третманот. Дел од овие пациенти биле потполно континентни, а дел имале значајно намалена фреквенција на инконтинентните епизоди ${ }^{12}$.

Во систематски преглед на 31 рандомизирана студија (1817 жени), кои ги испитувале ефектите на вежбите кај жени со стрес инконтиненција, докажано е дека веројатноста за подобрување на симптомите кај групата која ги спроведувала е 8 пати поголема од онаа група во која не биле спроведувани вежбите. Кај жените со останати типови на уринарна инконтиненција 5 пати била поголема веројатноста за подобрување на симптомите кај оние кои вежбале отколку кај оние кои не ги спроведувале вежбите ${ }^{11}$.

Тренингот со примена на вагинални конуси е специфичен тренинг на мускулатурата на карличното дно. Конусот се вметнува во вагината со поширокиот дел нагоре слично како тампон. Со цел да ја задржат 
соодветната тежина мускулите на карличното дно мораат да се контрахираат. Конусите се со различни тежини. Се започнува со конуси од 20 g, потоа тежината прогресивно се зголемува за по 12,5 g сѐ до $70 \mathrm{~g}$. Пациентките се обидуваат да ја задржат максималната тежина во период од 15 минути, два до три пати на ден. Во тек на вежбите пациентката стои на нозе. Доколку успешно го задржува конусот во тек на два дена, се напредува со задржување на конус со поголема тежина. Систематски преглед на 23 студии во кои биле вклучени 1806 жени со стрес инконтиненција, од кои 717 вежбале со вагинални конуси укажал дека оние кои вежбале со конуси имале значајно подобрување на симптомите ${ }^{13}$.

\section{Физикални агенси}

Од физикални агенси за подобрување на клиничкиот наод кај пациентите со уринарна инконтиненција се применуваат: биофидбек, функционална електрична стимулација, функционална магнетна стимулација и интерферентни струи.

Биофидбекот им помага на пациентите да ги модифицираат несвесните физиолошки настани. Се користат апарати со два сензора поставени во проекција на пелвичните мускули или интравагинално, а друг сет на сензори поставени на абдоменот. Преку компјутерски приказ или звучни сигнали пациентот добива информација дали соодветно врши мускулна контракација, а исто така може да се мери и силата на контракција. Овие информации помагаат да се индивидуализира програмот за вежби. Сесиите се со траење од 30 минути, 4 пати во тек на денот, секој ден, до 4 недели. Систематски преглед на 24 студии од Кохрановата база на податоци во кои биле вклучени 1583 жени го докажале позитивното дејство на биофидбекот во третман на уринарна инконтиненција. Жените кои примале биофидбек и применувале вежби имале значајно подобрување на симптомите 3 месеци по третманот во споредба со оние кои само вежбале и немале потреба од дополнителен третман ${ }^{14}$.

Функционалната електрична стимулација има за цел зајакнување на „перинеалната свест“, подобрување на тонусот и трофиката на мускулите на карличното дно и инхибиција на прекумерна активност на детрузорот. Предуслов за успешна стимулација е неоштетен рефлексен лак во сакралната регија и детрузор кој е способен да се контрахира. Перкутана иглена стимулација на задниот тибијален нерв е една од најшироко применуваните техники и наједноставна можност за апликација од овој тип на третман. Обично се користат бифазни импулси со времетраење од 20-700 микросекунди со фреквенција до $100 \mathrm{~Hz}$. Во комбинација со Кегелови вежби се постигнува редукција на фреквенцијата на мокрење и подобрување на квалитетот на живот кај 60\% од пациентите $\mathrm{e}^{9,15,16}$.

Во систематски преглед се изнесени резултатите од проценка на ефектите на електрична стимулација со неимплантирачки електроди, сама или во комбинација со друг третман на стрес инконтиненција или стрес предоминантно на мешан тип инконтиненција кај жени. Биле пронајдени 56 студии со вкупно 3781 учесници. Истражувањето индицира дека електричната стимулација веројатно е поефикасна во споредба со немање третман или лажен третман, но не било можно 
да се каже дали електричната стимулација е слична на примена на вежби за мускулите на пелвичното дно или некој друг активен третман во однос на ефикасноста ${ }^{17}$.

Интерферентни струи се применуваат кај стрес инконтиненција така што две електроди се поставуваат на предниот долен абдоминален sид, а другите две позади на крстната коска и на тој начин се опфаќа регијата на малата карлица. Притоа може да се одбираат различни фреквенции: од 0-100 Hz до 15 минути, 10 до $100 \mathrm{~Hz}$ за да се дразнат мускулите на карлицата и вегетативниот нервен систем или од 80 до $100 \mathrm{~Hz}$ до 10 минути. Се применува поголема амплитуда за да се предизвика максимално поднослива тетаничка контракција на мускулите на карличното дно. Сеансите би требало да траат еднаш дневно до три пати неделно ${ }^{18}$.

\section{Функционална магнетна стимула-} ција (ФМС) која некаде се нарекува екстракорпорална магнетна инервација претставува метод во физикална терапија која користи индукција на силно пулсирачко магнетно поле за да се постигне стимулација на мускулите на перинеалното дно кои имаат сочуван периферен моторен неврон. Тоа е неинвазивен, безболен метод кој овозможува безконтактна стимулација на површните и длабоките мускули под влијание на магнетно поле со јачина од 1,5 до 2 Тесли19. Фреквенцијата на полето е од 1 до $160 \mathrm{~Hz}$. Времетраењето на третманот е 10 до 20 минути. Најчесто се применува секој втор ден. Вообичаено се препорачува серија од 10 третмани.

Ефектите на магнетната стимулација се зголемување на силата и издржливоста на сфинктерите и мускулите на карлицата. Неколку клинички студии кои ја истражувале примената на магнетната стимулација кај уринарна инконтиненција покажале подобрување на уринарните симптоми (пр. редукција на фреквенцијата на испуштање урина, уродинамско подобрување, подобрување на максималниот капацитет на мочниот меур) без несакани ефекти ${ }^{20}$.

Хоскан и сор. го испитувале ефектот на екстракорпоралната магнетна инервација кај 30 пациенти со стрес уринарна инконтиненција, кои немале невролошки заболувања, ниту бременост. Третманот се состоел од сесии во траење од 20 минути, 2 пати неделно во тек на 6 недели. Контролите биле по 3, 12 и 24 месеци, при што уродинамски испитувања биле правени на почетокот на третманот и на првата контрола. По 3 месеци, 8 од 27 пациентки биле излекувани (29,7\%), а кај 13 пациентки (48,1\%) имало подобрување. Кумулативниот степен на успешност бил 77,8\%20.

Во ретроспективна опсервациона студија Вадала и сор. вклучиле 20 пациенти со уринарна инконтиненција, 10 жени и 10 мажи, со средна возраст од 64 г, 10 со стрес уринарна инконтиненција, 4 пациенти со ургентна уринарна инконтиненција и 6 пациенти со мешан тип на уринарна инконтиненција, кои биле третирани со функционална магнетна стимулација, сесија во траење од 20 минути, 2 пати неделно, во тек на 3 недели. Резултатите покажале значајно намалување на бројот на миктурациите и ноктуријата по терапијата $(\mathrm{p}<0,01)$. Уродинамските тестови покажале значајно зголемување на цистометрискиот капацитет, со максимален притисок при затворање на уретрата, трансмисијата на притисокот при контрола- 
та споредено со параметрите на почетокот на испитувањето. Авторите заклучиле дека овие прелиминарни резултати сугерираат дека функционалната магнетна стимулација може да биде ефикасна во третманот на уринарна инконтиненција ${ }^{7}$

Јаманиши и сор. објавиле резултати од мултицентрична рандомизирана, контролирана студија на примена на магнетна стимулација во фотелја споредено со примена на лажна магнетна стимулација кај 151 жена со ургентна уринарна инконтиненција. Магнетната стимулација се применувала со времетраење од 25 минути, два пати неделно, со максимална магнетна густина од $560 \mathrm{mT}$, пик од $10 \mathrm{~Hz}$, во тек на 6 недели. Било регистрирано значајно подобрување во испитуваната група во однос на епизодите на инконтиненција, волуменот и бројот на ургентност. Терапијата била безбедна за примена, освен што имало појава на дијареа и констипација. Авторите заклучиле дека магнетната стимулација е ефикасна во третманот на ургентна уринарна инконтиненција кај жени со преактивен мочен меур ${ }^{21}$.

Во неодамна објавен систематски преглед и мета-анализа биле евалуирани ефектите од примена на магнетна стимулација кај пациенти со уринарна инконтиненција. Биле анализирани 11 рандомизирани клинички испитувања со вкупно 612 пациенти. Според резултатите, магнетната стимулација ги намалувала симптомите на уринарна инконтиненција применувајќи го International Consultation on Incontinence Questionnaire-Short Form (ICIQ-SF) score, ja намалила фреквенцијата на уринарна инконтиненција и го подобрила квалитетот на живот на пациентите ${ }^{22}$.
Фармаколошката терапија вклучува примена на антихолинергици (оксибутинин, толтеродин) кои селективно ги блокираат мускаринските рецептори M2/M3 и спречуваат контракција на детрузорот при што се потиснуваат неинхибираните контракции и се зголемува неговиот капацитет. Антихолинергиците се корисни кај ургентна уринарна инконтинеција и хиперрефлексија на детрузорот. Но, несаканите ефекти (сува уста, опстипација, заматен вид, нарушување на когнитивните функции и дементна слика, сомноленција и конфузија), кои особено се присутни кај постарата полулација, водат кон ниска комплијанса. Кај преливна уринарна инконтиненција може да се вклучат $\beta 3$ адренергични агонисти (мирабегрон $)^{4,9}$. Неодамнешни студии укажале на висока ефикасност при третман на ургентна инконтиненција со онаботулинум токсин А (се инјектира во детрузорот). За жал, потребно е по 3 до 6 месеци реинјектирање заради повторна појава на симптомите ${ }^{23}$.

Хируршкиот третман е наменет за уринарна инконтиненција која не реагира на некој од горенаведените терапевтски можности. Слинг техники и суспензија на вратот на мочниот меур се наменети за решавање на стрес уринарна инконтиненција со цел реституција на нормалната позиција и поддршка на везикоуретралниот сегмент. Ургентна инконтиненција може да се третира со хируршко имплантирање на електрични стимулатори кои ги стимулираат сакралните, парауретралните и пуденталните нерви ${ }^{4,9}$.

Супортивен третман вклучува користење на влошки, пелени, песари, надворешен катетер во форма на кондом. Вагинална апликација на песари врши извесна компресија на 
вратот на мочниот меур и уретрата и го намалува уринарното истекување кај стрес инконтиненција ${ }^{10,24}$. За жал, премногу рана употреба, особено кај помлади пациенти кои соработуваат, може да ја влошат континенцијата давајќи им лажно чувство на сигурност и прифаќање на состојбата.

Со менување на социјалните ставови во друштвото и општеството станува јасно дека уринарната инконтиненција е далеку поголем проблем отколку што се мислело. Треба да се нагласи дека уринарната инконтиненција не е нормален дел од процесот на стареење и да се сфати како патолошка состојба на која и следува соодветен третман ${ }^{1,2}$. Симптомите на уринарна инконтиненција се ризик-фактор за низок квалитет на живот и имаат негативен ефект врз менталното здравје, професионалните и социјалните активности. Проблемите на уринарната инконтиненција се поврзуваат со сексуална дисфункција, слаби резултати на скалите за проценка на депресија и голем персонален и социјален трошок. Оттука и неопходноста да се максимизира ефикасноста на рутинскиот скрининг и ран третман.

\section{Заклучок}

Рехабилитационен третман со примена на вежби и физикални агенси кај пациенти со уринарна инконтиненција е значаен во обновување на континенцијата и подобрување на квалитетот на животот кај овие пациенти. Од најновиот преглед на литературата се заклучува дека со примена на кинезитерапија и функционална магнетна стимулација се намалува бројот на инконтинентни епизоди. Оваа комбинација води кон излекување или подобрување на симптомите на уринарна инконтиненција. Потребно е да се направат поголеми, со висок квалитет рандомизирани клинички испитувања со подолг период на следење за да се потврди ефикасноста на одделните методи.

\section{Референци}

1. Haylen BT, de Ridder D, Freeman R $M$, et al. An International Urogynecological Association (IUGA)/International Continence Society (ICS) joint report on the terminology for female pelvic floor dysfunction. Int Urogynecol J 2010; 21:5-26

2. Landefeld CS, Bowers BJ, Feld AD, et al. National Institutes of Health state-of-the-science conference statement: prevention of fecal and urinary incontinence in adults. Ann Intern Med 2008;148(6):449-458

3. Milsom I, Gyhagen M. The prevalence of urinary incontinence. Climacteric 2019;22(3):217-222.

4. Hersh L, Salzman B. Clinical management of urinary incontinence in women. Am Fam Physician 2013;87(9):634-40.

5. Линсенмејер АТ, Стоун МЏ, Стајнс AC. Неврогена дисфункција на мочниот меур и на цревата. Во: Делиса АЏ. Физикална медицина и рехабилитација. Принципи и практика. Том 2. Скопје: Табернакул; 2012:1618-1641

6. Pantazis K, Freeman RM. Investigation and treatment of urinary incontinence. Curr Obstet Gynaecol 2006;16:344-352.

7. Medical Advisory Secretariat. Behavioural interventions for urinary incontinence in community-dwelling seniors: an evidence-based analysis. Ont Health Technol Assess Ser 2008;8(3):1-52.

8. Vadala M, Palmieri B, Malagoli A, Laurino C. High-power magnetotherapy: a new weapon in urinary incontinence? Lower urinary tract 
symptoms. John Wiley\&Sons Australia, Ltd.2017.

9. Lukacz ES, Santiago-Lastra Y, Albo ME, Brubaker L. Urinary incontinence in women: a review. JAMA 2017;318(16):1592-1604.

10. DeMaagd A G, Davenport C T. Management of urinary incontinence. $\mathrm{P}$ T. 2012; 37(6): 345-361, 361B-361H.

11. Dumoulin C, Cacciari LP, Hay Smith EJC. Pelvic floor muscle training versus no treatment, or inactive control treatments, for urinary incontinence in women. Cochrane Database Syst Rev 2018; 2018(10): CD005654.

12. Riemsma R, Hagen S, Kirschner-Hermanns R, et al. Can incontinence be cured? A systematic review of cure rates. BMC Med 2017;15(1):63.

13. Herbison GP, Dean N. Weighted vaginal cones for urinary incontinence. Cochrane Database Syst Rev 2013;(7):CD002114.

14. Herderschee R, Hay-Smith EJ, Herbison GP, Roovers JP, Heineman MJ. Feedback or biofeedback to augment pelvic floor muscle training for urinary incontinence in women. Cochrane Database Syst Rev 2011;(7):CD009252

15. Ramírez-García I, Blanco-Ratto L, Kauffmann S, Carralero-Martínez A, Sánchez E. Efficacy of transcutaneous stimulation of the posterior tibial nerve compared to percutaneous stimulation in idiopathic overactive bladder syndrome: Randomized control trial. Neurourol Urodyn 2019; 38(1):261-268.

16. Moossdorff-Steinhauser HF, Berghmans B. Effects of percutaneous tibial nerve stimulation on adult patients with overactive bladder syndrome: a systematic review. Neurourol Urodyn 2013;32(3): 206-214.

17. Stewart F, Berghmans B, Bø K, Glazener CM. Electrical stimulation with non-implanted devices for stress urinary incontinence in women. Cochrane Database Syst Rev 2017;12:CD012390.

18. Jajić Y. Interferentne struje. U Fizikalna i rehabilitacijska medicina:osnove i liječenje. Ur. Jajić I. i sur. Medicinska Naklada, Zagreb, 2008, 164 - 171.

19. Klaus F. Functional magnetic stimulation, a new option in the therapy

of incontinence. Available from: www. urologie-salzburg.at

20. Hoscan MB, Dilmen C, Perk H, Soyupek S, Armagan A. Tukel O, Ekinci M. Extracorporeal magnetic innervation for the treatment of stress urinary incontinence: results of two-year follow-up. Urol Int 2008;81(2):167-72.

21. Yamanishi T, Homma Y, Nishizawa O, Yasuda K, Yokoyama O; SMN-X Study Group.Multicenter, randomized, sham-controlled study on the efficacy of magnetic stimulation for women with urgency urinary incontinence. Int J Urol 2014;21(4):395400.

22. He Q, Xiao K, Peng L, Lai J, Li H, Luo D, Wang K. An effective meta-analysis of magnetic stimulation therapy for urinary incontinence.Sci Rep 2019;9(1):9077.

23. Anger JT, Weinberg A, Suttorp MJ, Litwin MS, Shekelle PG. Outcomes of intravesical botulinum toxin for idiopathic overactive bladder symptoms: a systematic review of the literature. J Urol. 2010; 183(6):2258-64.

24. Richter HE, Burgio KL, Brubaker L. Continence pessary compared with behavioral therapy or combined therapy for stress incontinence: A randomized controlled trial. Obstet Gynecol 2010;115(3):609-617. 